\title{
Policy Synergy between The Provincial Government of East Java and The Central Government on Health Quarantine in The Treatment of Covid-19
}

\author{
Iman Pasu Marganda Hadiarto Purba \\ Program Studi PPKn, Fakultas IImu Sosial dan Hukum, Universitas Negeri Surabaya \\ Email: imanpurba@unesa.ac.id \\ I Made Suwanda \\ Program Studi PPKn, Fakultas IImu Sosial dan Hukum, Universitas Negeri Surabaya \\ Email:madesuwanda@unesa.ac.id \\ Agus Satmoko Adi \\ Program Studi PPKn, Fakultas Ilmu Sosial dan Hukum, Universitas Negeri Surabaya \\ Email: agussatmoko@unesa.ac.id \\ Rahmanu Wijaya \\ Program Studi PPKn, Fakultas IImu Sosial dan Hukum, Universitas Negeri Surabaya \\ Email: rahmanuwijaya@unesa.ac.id
}

\begin{abstract}
This study aims to examine the policy synergy between the Provincial Government of East Java and the Central Government in dealing with Covid-19. The urgency of this study is to explain to what extent policies between the Local Governments and the Central Government are in sync. This research uses legal research methods. Primary data includes statutory regulations, especially the Law on Health quarantine and secondary data such as previous research, expert opinion, and other relevant document data. This study concludes that the East Java Provincial Government and the Central Government have a synergy in dealing with Covid-19 in Indonesia. However, neither the legal products that are produced nor policies that are political in nature do not conflict with one another.
\end{abstract}

Keywords: Policy Synergy, Health Quarantine, Covid-19

\section{Abstrak}

Penelitian ini bertujuan untuk mengkaji sinergitas kebijakan antara Pemerintah Provinsi Jawa Timur dengan Pemerintah Pusat dan dalam menghadapi Covid-19. Urgensi penelitian ini adalah menjelaskan sejauhmana kebijakan antara Pemerintah Pusat dan Pemerintah Daerah sinkron. Penelitian ini menggunakan metode penelitian hukum. Data primer mencakup peraturan perundang-undangan terutama Undang-undang tentang karantina Kesehatan dan data sekunder seperti penelitian terdahulu, pendapat para pakar, dan data dokumen lain yang relevan. Kajian ini menyimpulkan bahwa Pemerintah Provinsi Jawa Timur maupun Pemerintah Pusat memiliki sinergi dalam menangani Covid-19 di Indonesia. Baik produk hukum yang dihasilkan maupun kebijakan yang bersifat politis, tidak bertentangan satu sama lain.

Kata Kunci: Sinergi Kebijakan, Karantina Kesehatan, Covid-19

\section{INTRODUCTION}

Indonesia is a unitary state as regulated in Article 1 the 1945 Constitution of the Republic of Indonesia. As a unitary state, the government is run by adhering to the principle of sharing authority between the central government and regional governments. In this context, the synergy between the Central Government and Regional Governments is a critical issue, including in handling Covid-19.
In the early days of the spread of Covid-19, many media reported that the government was hesitant to determine who had the most authority in tackling the spread of Covid-19. This is related to the division of government functions, where health affairs have been agreed as functions that are partially decentralized to local governments. Therefore, in the early days of handling the spread of Covid-19, some regional governments developed unilateral policies in dealing with the spread of Covid-19. This situation is not in line with

Article history: Received, 14 April 2021; Resivised, 05 Mei 2021; Accepted, 09 Mei 2021.

Corresponding author(s): Iman Pasu Marganda Hadiarto Purba,email: imanpurba@unesa.ac.id

To cite this article: Purba, I. P. M. H., Suwanda, I. M., Adi, A. S., \& Wijaya, R. (2021). Policy Synergy between The Provincial Government of East Java and The Central Government on Health Quarantine in The Treatment Of COVID-19. JPSI ( Journal of Public Sector Innovations ), 05(2), 43-51. https://doi.org/10.26740/jpsi.v5n2.p43-51 
the prevailing constitutional principle that a policymaking must prioritize harmony within the framework of a unitary state (Anwar: 2015, 44). Public policy must show the wisdom of the government towards the things the people want (Lubis, 2011: 204). One of them is that the central and regional governments must be synchronized in formulating policies, both political and legal policies, in handling Covid-19.

Meanwhile, the central government has also taken unilateral action against the handling of Covid-19. This is done because Covid-19 has been declared a world threat with a global emergency status, which means that the central government must respond to a public health emergency that requires serious handling. The central government's actions are also based on the fact that the quality of health services in the regions is low. Uneven health facilities and personnel in all regions can cause additional problems in handling Covid-19. Therefore, the central government took over the handling of the Covid19 case while still considering the regional government through the formation of a task force. This policy, although it seems slow, continues to improve its effectiveness. This is related to the implementation of decentralization of health affairs so that the fulfilment of basic public health is more secure (Chatarina, 2020: 3)

This fact shows that apart from health issues, Covid19 has raised other problems. Issues that include economic, social, cultural, security and governance. In government, the issue that arises is the relationship between the central and regional governments. In the case of Indonesia, the problem began when President Joko Widodo decided to choose Natuna Island as a quarantine place for 238 Indonesian citizens (WNI) who were evacuated from Wuhan City as the place for the spread of Covid-19.

The choice of Natuna Island as a place of quarantine has led to a demonstration by residents on February 1, 2020 (regional. Kompas.com, February 3, 2020). As a form of protest, the Natuna Regency Government issued a Letter (SE) Natuna Regional Secretary Number 8000 / DISDIK / 46/2000 dated February 2, 2020, regarding the policy of dismissing teaching and learning activities in Natuna Regency from February 3-17, 2020. This letter was finally revoked after the issuance of the letter from the Director-General of Regional Autonomy Number T.422.3 / 666 / OTDA concerning Orders to Revoke School Holidays for Post-Quarantine Students of Indonesian Citizens from Wuhan (Tempo, 2020, 3). The policies taken by the central government are related to health quarantine policies.

Referring to the Law Number 6, 2018, health quarantine is an effort to prevent and prevent the exit or entry of diseases and/or public health risk factors that have the potential to cause public health emergencies. This is directly related to the implementation of human development in Indonesia as a whole. There is a need for health protection for all Indonesian people.

In this contexts, it is interesting to examine how the policy synergy between the Central and Regional Governments. One area with a large population and a high risk of spreading is East Java. This study aims to analyze whether the policies of the central and regional governments are synchronous or contradictory. If it is conflicting, what is the background and how it can be assessed according to the existing laws and regulations. This research has an urgency to be taken into consideration by the central and local governments regarding the synchronization of policies in health quarantine, especially in response to COVID-19.

\section{METHOD}

This research uses normative legal research methods. This type of research is also known as doctrinal law research. The primary data of this research is written law products, namely statutory regulations (Amiruddin, 2004: 118). In addition, secondary legal materials are also known, namely materials that provide explanations about primary legal materials such as previous research, opinions of experts, and also drafts of laws. The tertiary legal materials are materials that support or explain primary and secondary legal materials such as legal dictionaries and encyclopedias. The policies and legal products issued by the central government and the regional government of East Java in handling Covid-19 were reviewed to see the synergy.

\section{RESULTS AND DISCUSSION \\ Corona Virus Disease 2019 (Covid-19) and Health Quarantine}

Severe Acute Respiratory Syndrome Coronavirus2 (SARS-CoV-2) is a very dangerous type of virus that has health, social and economic impacts. This virus is often more popularly known as Coronavirus Disease 2019 or (COVID-19). This virus was first discovered in Wuhan, Hubei Province. This virus spread massively to 190 countries. On March 12, 2020, the World Health Organitation (WHO) stated that COVID-19 is an epidemic referring to the number of cases that have emerged worldwide (Adityo, 2019: 3). Until August 18, 2020, Worldometers released data that there were 22,033,932 confirmed cases of COVID-19 in the world (22 million). on the same date, Indonesia had 141,370 confirmed cases. There were 94,458 people who recovered and 6,207 people died. The increase in Covid-19 cases in Indonesia continues to grow rapidly. There are no signs yet that this virus will stop spreading. On September 1, 2020, Kompas media reported that during the six months that this virus was found in Indonesia, the number of cases that emerged continued to increase rapidly, namely over 2000 patients in one day. On this date, the total number of Covid patients was 177,571. An increase of 2775 patients on that day (Dian, 2020: 13). The number is still very significant and is still a worrying category.

Referring to the COVID-19 Virus Prevention and Control Guidelines states that, based on scientific evidence, COVID-19 can be transmitted from human to human through close contact and droplets, not through the air. The people most at risk of contracting the disease are those who are in close contact with COVID-19 patients, including those who treat COVID-19 patients. Standard recommendations for preventing the spread of infection are through regular hand washing, applying the ethics of coughing and sneezing, avoiding direct contact with livestock and wild animals and avoiding close contact with anyone who shows symptoms of respiratory diseases such as coughing and sneezing. In addition, implement infection prevention and control (PPI) while in health facilities, especially emergency units (Fathiyah, 2020:5). This guideline is one of the references in formulating policies by the government.

Law of the Republic of Indonesia Number 4 of 1984 concerning Infectious Disease Outbreaks enacted 
on June 22, 1984, confirms that the realisation of the highest level of health for the people of Indonesia is one part of the national development goals. The state puts the health and safety of every citizen is the government's top priority in formulating its policies in the time of infectious outbreaks. It is also stated in this law that the development of technology, science, and international traffic, as well as environmental changes, can affect changes in disease patterns, including disease patterns that can cause outbreaks and endanger public health and can hinder the implementation of national development. National development mandated in the constitution will be hindered if the community threatened and worried about their health condition.

This health quarantine also reminds that Indonesia, as part of the world community, is committed to making efforts to prevent public health emergencies that are troubling the world as mandated in international regulations in the field of health. Its seriousness strongly influences the dignity and good name of the Indonesian nation in preventing and overcoming the Covid-19 outbreak that has occurred to date. Indonesia must fully respect the dignity, human rights, fundamentals of one's freedom, and its universal application. Promoting these basic fundamental rights becomes an integral part of ensuring the safety of Indonesian citizens.

One of the hardest government policies during the pandemic was the decision to quarantine health. What is meant by health quarantine is an effort to prevent and ward off the exit or entry of diseases and/or public health risk factors that have the potential to cause public health emergencies. So the ultimate goal of government policy to quarantine health is to prevent the occurrence of health emergencies. In the current context of Indonesia, the spread of Covid is still not well controlled due to various factors. Therefore, the policy to quarantine is one of the options that must still be considered.

When referring to regulations governing health quarantine, public health emergencies are defined as extraordinary public health events characterised by the spread of infectious diseases and/or events caused by nuclear radiation, biological pollution, chemical contamination, bioterrorism, and food that pose a health hazard and potentially spread across regions or across countries. Covid-19 certainly falls into the category of causes of health emergencies. Covid-19 has the potential to cause a health emergency in Indonesia. As an infectious disease that must still prevent and challenge its spread so as not to hinder the national development of this nation.

In warding off and preventing the outbreak of Covid-19, the government should not hesitate to quarantine. The quarantine is the restriction of activities and/or separation of a person exposed to infectious diseases as stipulated in the legislation even though it has not shown any symptoms or is in the incubation period, and/or separation of containers, Transports, or any Goods suspected to be contaminated from persons and/or Goods containing the cause of the disease or other sources of contamination materials to prevent possible spread to people and/or goods in the vicinity. In the context of handling Covid-19, it can be understood if quarantine is carried out for those diagnosed as Covid19 patients suspected of exposure to Covid-19 even though they have not shown any symptoms or are in the incubation period. Therefore, when the government issues a quarantine policy, the government also needs to describe the policy into a more specific policy, both policies for individuals, families, hospitals and regions.

For every citizen who is indicated or diagnosed as a Covid-19 patient or should be expected to be a Covid-19 patient, the policy is to isolate the citizen to prevent and counter the spread of Covid-19. According to the regulation in the health quarantine law, isolation is defined as the separation of sick people from healthy people conducted in health care facilities to get treatment and treatment. However, in addition to this, in the current context, the term self-isolation is also popular. It is intended that every citizen who wants to do self-isolation and, of course, under the supervision of health workers can be an option. In fact, many of the Covid-19 patients diagnosed as Asymptomatic Persons (OTG) patients do self-isolation. A good understanding of Covid-19 and its transmission and handling to every citizen is very important to do. Furthermore, selfisolation is done to ease the burden of the government in terms of hospital procurement that may be limited to the number of Covid-19 patients who are likely to increase the number of patients significantly.

The policy to quarantine the house is also one of the options that can be taken to ward off Covid-19. Home Quarantine is defined as a restriction on residents in a house and its contents that are suspected to be infected with the disease and/or contaminated in such a way as to prevent the possible spread of disease or contamination. This is done if, after conducting a series of tests or trials, and the whole house is considered infected with the Covid-19 virus, then it would be better for the whole house in quarantine not to infect other communities. Of course, in quarantine, the government house must still guarantee the survival of every family member in the house.

Therefore, the Central Government and Local Government are given legitimacy and power to solve the nation's problems according to the complicity (Sabian, 2008:37). In the legitimacy of issuing legal products at the regional level, it is best to follow the pattern at the central level (Asshiddiqie, 2011:8). The resulting legal product shall refer to the principles of legislation (Otong, 2013: 115). Synchronisation of rules that are legal policies issued by central and local governments should not conflict with each other

\section{Central Government Policy on Health Quarantine}

Government policy in the context of the state system clearly shows that there must still be synergy between institutions and authorities between institutions and authorities to achieve the goals and vision of the country. Authority and power cannot stand alone without being associated with other institutions. (Abdy, 2007, 67). In the context of the unitary state, then in the management of its power, the Central Government has its own role in deciding and executing policies in order to achieve the country's goals and national ideals, especially in the current pandemic era. However, this role is certainly in the context of the unitary state; the Central Government still has a relationship with the Local Government, both the relationship of authority, finance, public services, utilisation of natural resources 
and other resources that are implemented fairly in harmony (Nimatulhuda, 2016:102).

According to the Health Quarantine Law states that the Central Government is responsible for organising Health Quarantine at the entrance and in the region in an integrated manner. Organising Health Quarantine as intended by the Central Government can involve the Local Government. The intended entrance is the place of entry and exit of transportation, people, and/or goods, either in the form of ports, airports, or cross-border posts of the country that have the potential to accelerate the spread of Covid-19 determined through the determination issued by the government.

During the Covid-19 pandemic in every policy, central and local governments must ensure the availability of resources in the implementation of health quarantine. The law confirms that the Central Government and Local Government are responsible for the availability of resources needed in the implementation of Health Quarantine. The intended resources certainly not only refer to human resources but all the necessary needs in the face of Covid-19.

Law of the Republic of Indonesia Number 4 of 1984 concerning Infectious Disease Outbreaks enacted on June 22,1984 , confirms that the realisation of the highest level of health for the people of Indonesia is one part of the national development goals. The state puts the health and safety of every citizen as the government's top priority in formulating its policies in the time of infectious outbreaks. It is also stated in this law that the development of technology, science, and international traffic and environmental changes can affect changes in disease patterns, including disease patterns that can cause outbreaks and endanger public health and can hinder the implementation of national development.

The existence of each legislation certainly wants to fulfil the purpose of the law itself. If it refers to the purpose of the law, among others, to provide legal certainty, to provide justice, then the purpose of the law meets the sociological aspect becomes a much-needed thing. That is, fulfilling the legal feelings of society to create a sense of peace and prosperity. The state will have a hard time ensuring the welfare of its citizens if its public health is threatened. Therefore, the purpose and purpose of this law is to protect the population from the plague as early as possible in order to improve people's ability to live healthy lives.

In addition to the law governing infectious outbreaks as outlined above, the government must also take a policy for the handling of Covid-19, referring to Law Number 6, 2018 on Health Quarantine. This law confirms that in the framework of the implementation of human development, Indonesia is entirely required health protection for all Indonesians. Similarly, advances in transportation technology and the era of free trade can be at risk of causing health problems and new diseases or old diseases that reappear with faster spread and potentially cause public health emergencies, thus demanding efforts to prevent disease and health risk factors that comprehensive and coordinated, and requires resources, community participation, and international cooperation. The government should not be ignorant and apathetic to the safety of every Indonesian citizen.

Promoting these basic fundamental rights becomes an integral part of ensuring the safety of Indonesian citizens. When referring to regulations governing health quarantine, public health emergencies are defined as extraordinary public health events characterised by the spread of infectious diseases and/or events caused by nuclear radiation, biological pollution, chemical contamination, bioterrorism, and food that pose a health hazard and potentially spread across regions or across countries. Covid-19 certainly falls into the category of causes of health emergencies. Covid-19 has the potential to cause a health emergency in Indonesia. As an infectious disease that must still prevent and challenge its spread so as not to hinder the national development of this nation.

In countering and preventing the spread of Covid19 , the government should not hesitate to quarantine. Therefore, when the government issues a quarantine policy, the government also needs to describe the policy into a more specific policy, both policies for individuals, families, hospitals and regions.

The Central Government is the President of the Republic of Indonesia who holds the power of the government of the Republic of Indonesia assisted by the Vice President and ministers as referred to in the Constitution of the Republic of Indonesia year 1945. The minister in question is a minister who organises government affairs in the field of health that focuses on implementing health quarantine policies. In addition, the Central Government must synergise with the Local Government. The local government is the head of the region as an element of local government organisers who lead the implementation of government affairs that become the authority of the autonomous region. The context of the local government of regents, mayors and governors is the holder of executive power.

The Central Government and Local Government are responsible for protecting public health from diseases and/or Public Health Risk Factors that have the potential to cause Public Health Emergencies through the implementation of Health Quarantine. The Central Government and Local Government are mandated to protect all Indonesian. Certainly, one aspect that must be protected is the health aspect of every citizen. The government should not ignore the mandate of this constitution because somehow, they are obliged to maintain the sovereignty that the people give them.

In the implementation of health quarantine, both the Central and Local Governments are obliged to apply the following principles or principles, the principle of humanity, the principle of benefits, the principle of protection, the principle of justice, the principle of nondiscrimination, the principle of public interest, the principle of cohesion, the principle of legal awareness, and the principle of state sovereignty. All of these principles become a reference in formulating regulations or norms that are considered to be specific to health quarantine, especially the handling of Covid-19. A number of regions have previously decided to quarantine areas or local lockdown, such as Tegal, Tasikmalaya City, Makassar, and Ciamis, as well as Papua Province. Jokowi did not respond directly to the policies taken by these areas. Nevertheless, he asked his ministers to ensure that every policy taken by the local government is in line with the policy at the centre. The President previously asserted that local governments must synergise with the Central Government. Lock Down or Quarantine Area is strictly regulated as the authority 
of the Central Government for the benefit of the State (Ihsanudin, 2020:5).

Funding for health quarantine activities comes from the state budget, regional revenue and expenditure budgets, and/or the community. On March 31, 2020, the President of the Republic of Indonesia issued a Replacement Government Regulation Law No. 1, 2020 (PERPPU 01/2020) on State Financial Policy and Financial System Stability for the handling of the Corona Virus Disease Pandemic 2019 (Covid-19) and/or in order to Deal with Threats That Endanger the National Economy and/or Financial System Stability. The total budget for this is Rp 405.1 trillion (Embassy of Belgium, 2020, 1) stated that On April 3, 2020, the President issued Presidential Regulation (Perpres) No. 54 of 2020 on Changes in Detailed Posture and State Budget year 2020. This presidential regulation is a follow-up to Perppu No. 1, 2020. As a result, the budget of several ministries was cut by Rp 97.42 trillion. However, some ministries have increased budgets, such as the Ministry of Education and Culture by $\mathrm{Rp} 36$ trillion to $\mathrm{Rp} 70$ trillion; and the Ministry of Health from Rp 57 trillion to 76 trillion.

Presidential Decree of the Republic of Indonesia concerning the Task Force to Accelerate the Implementation of Corona Virus Disease 2019 (COVID19) which was determined on March 13, 2020. The weighing section states that the spread of COVID-19 in the world tends to continue to increase over time, causing greater fatalities and material losses, and has implications for the social, economic, and welfare aspects of society; that world health organisation (WHO) has declared COVID-19 as Pandemic on March 11, 2020; that there have been certain circumstances with the transmission of COVID-19 in Indonesia that need to be anticipated the impact; that in order to accelerate the handling of COVID-19, swift, precise, focused, integrated, and synergistic measures are needed between ministries/institutions and local governments.

The second strategy is tracing positive cases treated using rapid tests or rapid tests. Among them are those closest, health workers who treat COVID-19 patients, as well as in communities in areas where there are many cases. The government determines the policy to conduct screening or screening examination with a rapid test. Rapid test tool Has been distributed more than 450 thousand kits throughout Indonesia. The goal is to network contact tracking cases on health workers and communities in areas with a large number of positive cases. The third strategy is the education and preparation of isolation independently in some tracing results that show positive test results from rapid tests or negative with symptoms to perform self-isolation. This isolation can be done independently or in groups as initiated by some community groups. This is positively appreciated. So that our brothers can do well without stigmatisation and efforts to isolate.

National disaster management caused by the spread of Covid-19 is carried out by the Task Force to Accelerate the Handling of Corona Virus Disease 2019 in accordance with Presidential Decree No. 7 of 2020 concerning the Task Force to Accelerate the Handling of Corona Virus Disease 2019 as amended by Presidential Decree No. 9 of 2020 concerning Amendments to Presidential Decree No. 7 of 2020 concerning Task Force to Accelerate The Handling of Corona Virus Disease 2019 through synergy between ministries/ agencies and local governments. Governors, regents, and mayors, as the Chairman of the Task Force to Accelerate the Handling of Corona Virus Disease 2019 (COVID-19) in the region, in setting policies in their respective regions, should pay attention to the policies of the Central Government.

\section{B. East Java Province Policy on Health Quarantine}

Referring to the Health Emergency Law, the Central Government and Local Government is responsible for protecting public health from diseases and/or Public Health Risk Factors that have the potential to cause Public Health Emergencies through the implementation of Health Quarantine. Of course, the context of the current pandemic of East Java Province must also take part in it considering in terms of the spread of Covid-19. Even East Java was once one of the provinces with the highest spread of Covid-19 at the national level.

The latest data update on September 29, 2020, The number of Covid-19 positive patients is 43,450 people, with details, 3580 people in treatment, declared cured 36,780 and died 3162 people (Jatim Tanggap, 2020,1). The red zone for the spread of COVID-19 in East Java is currently in six districts and cities. Red zone means areas that have a high risk of the spread of Coronavirus. Data collected from the Task Force on The Acceleration of Handling COVID-19 in East Java details six districts and cities whose status is a red zone, namely Sidoarjo, Probolinggo, Pasuruan City, Pasuruan, Banyuwangi and Malang (Hilda, 2020:1). This shows that the Government of East Java should give serious attention to handling COVID-19.

The law governs the Central Government and Local Government responsible for the availability of resources required to implement Health Quarantine. As previously stated, governors, regents, and mayors as the Chairman of the Task Force to Accelerate the Handling of Corona Virus Disease 2019 (COVID-19) in the region set policies in their respective regions should pay attention to the policies of the Central Government. Article 12 of Law No. 4 of 1984 stipulates that (1) the Head of the Local Region /Region who is aware of the suspected outbreak in his area or the presence of suspected infectious disease sufferers who can cause an outbreak must immediately take countermeasures as necessary. (2) The countermeasures referred to in paragraph (1) shall be stipulated by the laws and regulations. Responsive countermeasures are the obligation of the local government to be taken immediately.

Article 49 of Law No. 8 of 2018 on Health Policy stipulates that (1) In order to mitigate risk factors in the region in the situation of Public Health Emergency conducted Home Quarantine, Regional Quarantine, Hospital Quarantine, or Large-Scale Social restrictions by Health Quarantine officials. (2) Home Quarantine, Regional Quarantine, Hospital Quarantine, or Large-Scale Social Restrictions as referred to in paragraph (1) shall be based on epidemiological considerations, the magnitude of the threat, effectiveness, resource support, operational technical, economic, social, cultural, and security considerations.

Article 59 (1) large-scale social restrictions (PSBB) is part of the Public Health Emergency response. (2) LargeScale Social Restrictions are aimed at preventing the widespread of public health emergencies that are occurring among people in a particular region. (3) Large- 
Scale Social Restrictions as referred to in paragraph (1) shall include at least: a. the disbursement of schools and workplaces; b. restrictions on religious activities; and/or c. restrictions on activities in public places or facilities. (4) Implementation of Large-Scale Social Restrictions in coordination and cooperation with various relevant parties in accordance with the provisions of the laws and regulations. In the context of East Java, the Province, in this case, the Governor decided to treat the PSBB.

The East Java Provincial Government Policy regarding COVID-19 began with the release of East Java Governor Regulation No. 18 of 2020 concerning Guidelines for Large-Scale Social Restrictions in the Handling of Corona Virus Disease 2019 (Covid-19) in East Java Province. This regulation was issued on April 22,2020 . Although the policy of the central government through regulations and decisions regarding Covid-19 has been issued in March. Both concerning the establishment of Covid-19 as a non-natural disaster are national disasters, health emergency provisions, the establishment of a task force to accelerate the handling of Covid-19 and concerning the implementation of PSBB.

The Government of East Java Province also issued East Java Governor Regulation No. 21 of 2020 concerning Amendments to East Java Governor Regulation No. 18 of 2020 concerning Guidelines for Large-Scale Social Restrictions in the Handling of Corona Virus Disease 2019 (Covid-19) in East Java Province. The Next East Java Regional Government also issued a Decree of the Governor of East Java Number 188/108/KPTS/013/2020 concerning the Emergency Status of Disease Outbreaks Due to Corona Virus Disease 2019 (COVID-19) in East Java. Changes are made to the rules based on the evaluation results from the previous PSBB preparation stage, it is necessary to make some adjustments to the implementation of the PSBB. For example, during the implementation of PSBB, restrictions are placed on the process of working in the workplace. During the limitation of the process of working in the workplace/office as intended replaced with the process of working at home/residence to maintain the productivity/performance of workers. During the limitation of the work process in the workplace/office as referred to in paragraph, must still assign employees or security officers to maintain the workplace/office.

During the implementation of PSBB, every resident in the District/City has the same right to obtain treatment and services from the Provincial Government and the District / City Government, get basic health services according to medical needs, obtain data and information about COVID-19, ease of access in making complaints related to COVID-19; and COVID-19 repatriation, ambulance and funeral services. In fulfilment of the rights as intended is carried out in accordance with the technical instructions set by the Regent/Mayor. Regulation of the Regent/Mayor as the implementation and technical instructions of the Regulation of the Governor on PSBB is determined no later than 2 (two) days since the determination of the Governor's Decision on the implementation of PSBB in the district/city in question.

After the regulation on PSBB by the Governor of East Java, the Regional Government again issued a Decree of the Governor of East Java No. $188 / 202 /$ Kpts/013/2020 concerning the
Implementation of Large-Scale Social Restrictions in the Handling of Corona Virus Disease 2019 (Covid-19) in Surabaya, Sidoarjo, and Gresik districts. This determination is taken. Based on the Decree of the Minister of Health Number HK.01.07/MENKES/264/2020 concerning the Establishment of Large-Scale Social Restrictions in Surabaya, Sidoarjo, and Gresik districts, East Java Province in order to accelerate the handling of Corona Virus Disease 2019 (COVID-19), so it is necessary to establish its implementation.

The determination is the One Enforcement of Large-Scale Social Restrictions (PSBB) in the Handling of Corona Virus Disease 2019 (COVID19) in Surabaya, Sidoarjo, and Gresik districts for 14 (fourteen) days, starting from April 28, 2020, to May 11, 2020, Second, In the event that there is still evidence of the spread of COVID-19 at the end of the implementation of PSBB as intended in consideration that the implementation of PSBB can be extended. This is regulated because the certainty of the level of spread of Covid-19 is influenced by various factors, especially strongly influenced by public adherence to health protocols.

Ensuring legal policy at the Provincial level with districts and cities synchronise each other on the implementation of PSBB, then on April 22, 2020, the Regional Secretary of East Java Province socialised the draft Regulation of the Governor (Pergub) East Java on PSBB to the Surabaya Municipality, Sidoarjo Regency and Gresik Regency. East Java Provincial Government will listen to presentations from representatives of each region to deliver the Surabaya Mayor Regulation, Sidoarjo Regent Regulation and Gresik Regent Regulation. Synchronisation of these regulations is very important so that significant and measurable results in the cessation of Covid-19 can be achieved in line with each district. Because there are different points and each Regent and Mayor has a priority to prepare the details of the plan from the detailed derivatives of the Governor's Regulation.

Similar to the Central level, at the Provincial level, the East Java Regional Government also formed a Joint Team (Regional Leadership Communication Forum) Forkopimda East Java and the Task Force Surabaya Raya, namely Surabaya, Sidoarjo, Gresik. The three areas became the highest spreading areas in East Java in coordination with Pangkogabwilhan II. Khofifah said that the formation of this team aims to intensify coordination in synergy, collaboration, and evaluation. In addition, it is expected that these three cities share measurable resources and commitments and also continue to facilitate more tests, tracking, isolation, and treatment or treatment.

The East Java Governor said the East Java Provincial Government prepared a budget for handling Covid-19 amounting to more than $\mathrm{Rp} 2.3$ trillion. The amount is called equivalent to 6.8 per cent of the total Budget of East Java 2020, amounting to Rp 35 trillion, equivalent to 6.8 per cent of the budget of East Java Budget 2020. The budget will be used for various activities handling Covid-19 in East Java for curative activities, tracing, and handling the socioeconomic impacts of citizens due to the Covid-19 outbreak. The budget absorption of the East Java Provincial Government is still far below the target. This was revealed when Indonesian President Joko Widodo gave 
directions to the Governors of Indonesia at the Bogor Presidential Palace late last week. The budget absorption of East Java Provincial Government was still at 30 per cent in the third quarter. East Java is in 16th place, lagging far behind the Special Capital Region Province (DKI) Jakarta.

The Government of East Java Province prepared a social safety net (Bansos) for residents affected by Covid-19. The first is the supplement 'Bansos' and the coating of Non-Cash Food Aid (BPNT), then also the food/cash assistance program through Special Financial Assistance (BKK), and social assistance stalls around boarding schools, and began to be enjoyed by residents affected by Covid-19 in East Java is a coating fund for the families of beneficiaries (KPM) non-cash food assistance (BPNT) based on the village. The funds have been transferred to each village-based KPM account through the replenishment of each KPM BPNT account at the channelling bank, namely Bank Himpunan Bank Milik Negara (Himbara).

With this intervention, every village-based KPM not only gets 200,000 rupiahs in food aid from the central government. But also added a top-up of Rp100 thousand from the Provincial Government. Total KPM amounted to 333,022 beneficiary families. The total assistance from the East Java Provincial Government reached Rp99.906 billion. This additional top-up will be done three times over the next three months. Three areas that are implementing Large-Scale Social Restrictions (PSBB), namely the city of Surabaya, get a top-up from the East Java Provincial Government there is as many as 118,758 KPM, which is equivalent to Rp5.62 billion. Sidoarjo regency that received this top up there are as many as $6,773 \mathrm{KPM}$ which is equivalent to the total value of $\mathrm{Rp} 2$ billion, and Gresik district gets top-up assistance as much as 3,448 KPM or equivalent (Kominfo Jatim, 2020:1)

The efforts of the Regional Leadership Communication Forum (Forkopimda) of East Java Province, ranging from socialisation, education, testing, tracing, treatment and operation of health protocol violations, successfully lowered the average case of Suspect Covid-19 in East Java. Rapid test efforts as many as 933,082 have been conducted, and as many as 288,304 PCR tests. This rapid test number is the highest in Indonesia. While the PCR test in the period May September 2020, the second-highest PCR test in Indonesia after Jakarta.

The optimisation of treatment will also be done by referring to the guidelines of the Ministry of Health and professional organisations. Furthermore, an early warning system will be developed to prevent depleted drugs to ensure the need for enough drugs to reduce deaths in ICU isolation. Added to mitigating the risk of COVID-19 in medical personnel, East Java Provincial Government and BNPB Health Task Force will prepare lodging facilities for doctors and health workers who serve in referral hospitals and ensure adequate nutrition.

\section{Policy Synergy between the Provincial Government of East Java and the Central Government regarding Health Quarantine.}

In the implementation of health quarantine, both the Central and Local Governments are obliged to apply the following principles or principles, humanitarian principles, principles of benefit, principles of protection, principles of justice, non-discriminatory principles, principles of public interest, principles of integration, principles of legal awareness, and the principle of state sovereignty. Law Number 6, 2018, concerning the Health Quarantine, is a reference for the central and regional governments to be in the same vision line. This regulation is in no way contradicting the constitution because the derivative of the constitution or statute cannot contradict the laws and regulations under it (Ellydar: 2007, 93). Previously, the government had issued a Government Regulation (PP) on Large-Scale Social Restrictions and a Presidential Decree (Presidential Decree) on Public Health Emergencies, which became the implementing rules and policy basis for the government in dealing with the impact of Covid19. The Central Government ensures that the steps currently being taken by the government are steps that have previously been calculated and adapted to the existing conditions in Indonesia, including geographical conditions, demographics, cultural characteristics, discipline, and fiscal capacity. The government has even studied the steps and policies taken by a number of countries in handling the Covid-19 case.

The management guidelines for handling Covid-19 include 5 (five) strategies, namely; First, a strategy to prevent the spread of Covid-19; Second, increase the immune system; Third, increasing the capacity of the health system; Fourth, increasing food security and the medical device industry; Fifth, strengthen social safety nets. The Central Government has asked the Regional Government to refocus the 2020 budget through the APBD. This is an effort to deal with the spread and transmission of Covid-19 in the regions and its impacts. The total amount of APBD that has been relocated is approximately Sixty-seven trillion rupiahs throughout Indonesia, all directed towards the fight against Covid19.

Another effort made by the Central Government is signing a cooperation contract during a visit to China and the United Arab Emirates to procure the Covid-19 vaccine. As a result, a total of 290-340 million doses of the Covid-19 vaccine will be available in 2021. For the first quarter, the vaccines that have been obtained are between 80-130 million.

The President of the Republic of Indonesia issued a Government Regulation in lieu of Law No.1 of 2020 (PERPPU 01/2020) concerning State Financial Policy and Financial System Stability for Handling the 2019 Corona Virus Disease Pandemic (Covid-19) and/or in the Context of Facing Threats that Endanger the National Economy and/or Financial System Stability. The total budget for this is 405.1 trillion rupiahs. Meanwhile, East Java Governor Khofifah Indar Parawansa said that the East Java Provincial Government had prepared a budget for handling Covid-19 of more than IDR 2.3 trillion. This amount is equivalent to 6.8 per cent of the total East Java 2020 APBD of IDR 35 trillion, equivalent to 6.8 per cent of the 2020 East Java APBD budget. The budget will be used for various activities to handle Covid-19 in East Java, such as curative activities, tracing, and handling the socio-economic impacts of residents due to the Covid-19 outbreak.

Government Regulation Number 21 of 2020 concerning Large-Scale Social Restrictions (PSBB) in the Context of Accelerating the Handling of Corona Virus Disease 2019 (COVID-19). This regulation was issued on March 31, 2020. The part considering it states that the 
spread of COVID-19 with the number of cases and / or the number of deaths increases and extends across regions and across countries and has an impact on political, economic, social, cultural, defense and security aspects. The spread of COVID-19 has resulted in certain conditions so that it is necessary to make countermeasures, one of which is through large-scale social restriction measures. This is in sync with the East Java Provincial Government Policy regarding COVID-19. Starting with the issuance of the Governor of East Java Regulation Number 18 of 2020 concerning Guidelines for Large-Scale Social Restrictions (PSBB) in Handling Covid-19. This regulation was issued on April 22, 2020. Even though the central government policy regarding Covid-19 was issued in March. regarding the designation of Covid-19 as a non-natural disaster is a national disaster, the provision of a health emergency, the establishment of a task force to accelerate the handling of Covid-19 and regarding the implementation of the PSBB.

Presidential Decree Number 7 of 2020 concerning the Task Force for the Acceleration of Handling Covid-19 as amended by Presidential Decree Number 9 of 2020 concerning Amendments to Presidential Decree Number 7 of 2020 concerning the Task Force for the Acceleration of Handling Covid-19 through synergy between ministries / agencies and local governments. This is in sync with the policies of the East Java Provincial Government which also formed the Joint Team, the East Java Regional Leadership Communication Forum (Forkopimda) and the Greater Surabaya Task Force, namely the City of Surabaya, Sidoarjo Regency, Gresik Regency. These three areas are the highest distribution areas in East Java.

To deal with Covid-19, both the Central and Local Governments agreed to take Tracing, Testing and Treatment seriously. Therefore, so far there is no policy of the East Java Provincial Government that contradicts the existing policies of the Central Government.

\section{CLOSING}

\section{Conclusions}

The Central Government and the East Java Provincial Government have a synergy in dealing with Covid-19 in Indonesia. Neither the legal products that are produced nor policies that are political in nature do not conflict with one another. These two government agencies have worked to protect every citizen from the Covid-19 outbreak. This is in line with the state's goal of protecting the entire nation. Apart from that, through various financial policies, the two government institutions have also made efforts to protect the general welfare as mandated by the constitution. Another effort made is through the Ministry of Education by providing various policies and programs that are appropriate to help people access education in a pandemic situation.

\section{Suggestions}

The East Java Provincial Government and the Central Government must maintain synchronization of policies related to Covid-19, which refer to statutory principles. The law mandates synchronization. Regulations made by regional government agencies must be in line with higher government agencies. At the same time, every policy taken must prioritize the principles of autonomy and pay attention to the uniqueness and special situation of certain regions.

\section{REFERENCES}

Abdy Yuhana, 2007, Sistem Ketatanegaraan Indonesia Pasca, Perubahan UUD 1945, Fokus Media: Bandung

Adityo Susilo, 2020, Coronavirus Disease 2019: Tinjauan Terkini, Universitas Indonesia

Anwar, 2015, Teori dan Hukum Konstitusi, Setara Press: Malang

Ellydar, 2007, Hukum dan Teori Konstitusi, Total Media: Yogyakarta.

Fathiyah Isbaniah, Sp.P(K), FISR (PDPI) dkk, 2020, Pedoman Pencegahan dan Penanggulangan Covid-19, Direktoran Jenderal Pencegahan dan Pengendalian Penyakit Kemenkes

Jimly Asshiddiqie, 2011, Hukum Tata Negara \& PilarPilar Demokrasi, Jakarta: Sinar Grafika.

Ni'matul Huda, 2016, Sengketa Kewenangan Lembaga Negara, Yogyakarta, FH UII Pres.

Otong Rosadi, 2012, Studi Politik Hukum, Yogyakarta: Thafa Media.

Riris Catarina, 2020, Relasi Pemerintah PusatPemerintah Daerah Didalam Menanggulangi Covid19, Pusat Badan Keahlian DPR RI

Sabian Utsman, 2008, Menuju Penegakan Hukum Responsif, Yogyakarta: Pustaka Pelajar

Solly Lubis, 2011, Serba-Serbi Politik Hukum, Soft Media: Jakarta

Dian erika, Update: Kasus Covid-19 di Indonesia kini 177.571

bertambah https://nasional.kompas.com/read/2020 /09/01/15110111/update-kasus-covid-19-

indonesia-kini-177571-bertambah-2775?page =all diakses 2 September 2020

Ihsanuddin, Jokowi Menegaskan Bahwa Keputusan Karantina Wilayan adalah Pusat, Jakarta: Kompas. https://nasional.kom pas.com/read/2020/03/30/15063361/presidenjokowi-kembali-tegaskan-karantina-wilayahwewenang-pusat

Hilda Meilisa, 6 Kabupaten/Kota Kembali Zona Merah, Ini data Terbaru Covid-19 di Jatim, Surabaya: Detik. https://news.detik.com/berita-jawa-timur/d-

5168540/6-kabupatenkota-kembali-zona-merah-inidata-terbaru-sebaran-corona-di-jatim diakses 29 September 2020

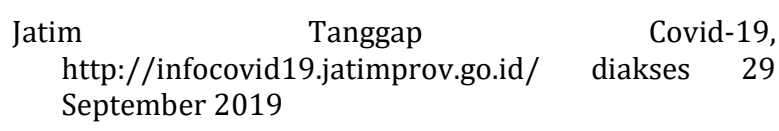

Kominfo Jatim, Gubernur Jatim Siapkan Bantuan Untuk Warga Terdampak Covid-19, http://kominfo.jatimprov.go.id/read/umum/gubern ur-jatim-siapkan-program-bantuan-untuk-wargaterdampak-covid-19 diakses tanggal 30 September 2020 
Nusa Daily, Covid-19 Jatim: Kesembuhan Meningkat, Rata-rata Positif Turun, https://nusadaily.com/jatim/covid-19-jatimkesembuhan-meningkat-rata-rata-positif-turun.html. Diakses 08 Oktober 2020

Rahmat Nur Hakim, Menlu Sebut Pengadaan Vaksin Covid-19 atas Kerjasama dengan UEA, Jakarta: Kompas.https://nasi onal.kompas.com/read/2020/08/24/19340371/me nlu-sebut-pengadaan-vaksin-covid-19-atas-kerjasama-dengan-china-dan-uea?page $=$ all

Undang-Undang Republik Indonesia Nomor 4 Tahun 1984 Tentang Wabah Penyakit Menular

Undang-Undang Nomor 4 Tahun 1984 tentang Wabah Penyakit Menular

Undang-Undang Nomor 24 Tahun 2007 tentang Penanggulangan Bencana

Undang-Undang Nomor 6 Tahun 2018 tentang Kekarantinaan Kesehatan

Undang-Undang Nomor 36 Tahun 2009 tentang Kesehatan

Undang-Undang Nomor 23 Tahun 2014 tentang Pemerintah Daerah

KBRI BELGIA, Kebijakan Pemerintah RI terkait Covid-19, Brussel:

Kemenlu,https://kemlu.go.id/brussels/id/news/634 9/kebijakan-pemerintah-republik-indonesia-terkaitwabah-covid-19, diakses tanggal 29 september 2019

Peraturan Pemerintah Pengganti Undang-Undang Nomor 1 Tahun 2020 tentang Kebijakan Keuangan Negara dan Stabilitas Sistem Keuangan Untuk Penanganan Pandemi Corona Virus Disease 2019 (COVID-19) dan/atau Dalam Rangka Menghadapi Ancaman Yang Membahayakan Perekonomian Nasional dan/atau Stabilitas Sistem Keuangan

Peraturan Pemerintah Nomor 40 Tahun 1991 tentang Penanggulangan Wabah Penyakit Menular

Peraturan Pemerintah Nomor 33 Tahun 2018 tentang Pelaksanaan Tugas dan Wewenang Gubernur Sebagai Wakil Pemerintah Pusat

Peraturan Gubernur Jawa Timur Nomor 21 Tahun 2020 Tentang Perubahan Atas Peraturan Gubernur Jawa Timur Nomor 18 Tahun 2020 Tentang Pedoman Pembatasan Sosial Berskala Besar Dalam Penanganan Corona Virus Disease 2019 (Covid-19) Di Provinsi Jawa Timur

Keputusan Gubernur Jawa Timur Nomor 188/202/Kpts/013/2020 Tentang Pemberlakuan Pembatasan Sosial Berskala Besar Dalam Penanganan Corona Virus Disease 2019 (Covid-19) Di Wilayah Kota Surabaya, Kabupaten Sidoarjo, Dan Kabupaten Gresik

Keputusan Presiden Nomor 7 Tahun 2020 tentang Gugus Tugas Percepatan Penanganan Corona Virus Disease 2019 (COVID-19) 